\title{
MĄDROŚĆ WYCHOWAWCZA ELŻBIETY CZACKIEJ FSK UJAWNIONA W STOSUNKU DO LUDZI NIEWIDOMYCH I SŁABOWIDZĄCYCH
}

\section{The Educational Wisdom of Elizabeth Czacka FSK Revealed in Relation to the Blind and Dim-sighted}

Summary: A specific type of interpersonal interaction is the relation between an educator and their student. It is on this plane that the metaphysics of help is revealed: the educator is obliged to support their student in fulfilling their humanity. Such an attitude is exemplified by the founder of the Society for the Care of the Blind, Mother Elżbieta Róża Czacka, who helped her blind students to release all of their resources and abilities, especially those hidden and marginalised ones, to make them lead a possibly self-reliant and independent life. The phenomenon of the educational concept of Róża Czacka - in addition to the affirmation of the personal dignity of her students - relies on respecting the value of truth and consistency together with imposing realistic requirements on people with visual disabilities. Her own blindness made her realise that this kind of disability is a severe limitation, but thanks to her personal belief in God she could find meaning in her life, which became service to the blind, especially children.

Keywords: student, educator, visual disability, dignity, suffering

1 Dr Małgorzata Łobacz - adiunkt w Katedrze Biografistyki Pedagogicznej Instytutu Pedagogiki w Katolickim Uniwersytecie Lubelskim Jana Pawła II. Adres: Instytut Pedagogiki KUL, ul. Droga Męczenników Majdanka 70, 20-325 Lublin; e-mail: gkolomanska@wp.pl. 


\section{Wstęp}

Matka Elżbieta Róża Czacka² - znana jako założycielka Dzieła Lasek (Towarzystwa Opieki nad Ociemniałymi Triuno oraz Zgromadzenia Sióstr Franciszkanek Służebnic Krzyża) - będąc niewidomą, całkowicie poświęciła swoje życie osobom ociemniałym (zarówno na duszy, jak i na ciele). W sposób heroiczny starała się dla ludzi doświadczonych kalectwem wzroku o miejsce, w którym mogliby nauczyć się żyć możliwie samodzielnie i czuć się w pełni wartościowymi osobami.

Celem niniejszego artykułu będzie ukazanie postawy mądrości wychowawczej Matki Elżbiety Róży Czackiej ujawnionej w stosunku do ludzi niewidomych i słabowidzących ze szczególnym uwzględnieniem aksjologicznych podstaw wychowania, metod wychowania, roli wychowawcy w udzielaniu wsparcia podopiecznym oraz błędów popełnianych przez wychowawców ludzi niewidomych i słabowidzących. Sformułowany problem badawczy brzmi następująco: Na czym polega istota mądrości wychowawczej Elżbiety Czackiej ujawniona w stosunku do ludzi niewidomych i słabowidzących i co stoi u jej podstaw?

\section{Wychowanie jako pomoc w dążeniu do pełni człowieczeństwa}

Wychowanie każdego człowieka opiera się przede wszystkim na rozpoznaniu jego osobowej godności, a zatem na odkryciu tego, co w nim podstawowe, niezbywalne i trwałe. Poznanie godności z kolei nie pozwala pozostać obojętnym wobec wychowanka, zobowiązuje wychowawcę do podjęcia aktywności. Owa aktywność przejawia się w szacunku do wartości rozpoznanej godności oraz w gotowości do niesienia pomocy wychowankowi w realizacji jego człowieczeństwa ${ }^{3}$.

Najwyższym kryterium godności jest miłość, która nie dopuszcza do instrumentalnego traktowania człowieka. Świat osób w całym swym zakresie jest więc

2 Róża Maria Czacka urodziła się 22 października 1876 roku w Białej Cerkwi. Była prawnuczką Tadeusza Czackiego - twórcy Liceum Krzemienieckiego. Ojcem jej był Feliks Czacki, matką zaś Zofia z Ledóchowskich. Od dzieciństwa miała problemy ze wzrokiem, który ostatecznie straciła w 22. roku życia. Kolejne dziesięć lat przyszła Matka Czacka poświęciła na usprawnienie swojego życia doświadczonego niepełnosprawnością, uczyła się samodzielności. Ponadto opanowała alfabet Braille’a, poznała najnowsze osiągnięcia nauki o niewidomych. Na fundamencie tych doświadczeń powołała w 1911 roku Towarzystwo Opieki nad Ociemniałymi w Warszawie, które funkcjonuje do dziś (w Laskach), zaś w 1918 roku za przyczyną Róży Czackiej powstało nowe zgromadzenie Sióstr Franciszkanek Służebnic Krzyża, którego celem jest służba niewidomym na duszy i ciele. Matka Elżbieta Róża Czacka zmarła w opinii świętości 15 maja 1961 roku w Laskach [Rut Wosiek, „Czacka Róża”, w: Encyklopedia katolicka, red. Romuald Łukaszyk, Ludomir Bieńkowski, Feliks Gryglewicz (Lublin: Towarzystwo Naukowe KUL 1979), t. 3, 745-746].

3 Wojciech Chudy, Pedagogia godności. Elementy etyki pedagogicznej, red. Anna Szudra (Lublin: Towarzystwo Naukowe KUL 2009), 57. 
dla istoty ludzkiej - podmiotu działania moralnego - „polem odpowiedzialnej miłości”" Róża Czacka, jako osoba pochodząca z wyższych sfer, oczytana i refleksyjna, wiedziała, że ludzie z niepełnosprawnością traktowani są jako społecznie niewartościowi, często izolowani. Jej kalectwo również początkowo było ukrywane przez najbliższych ${ }^{5}$. Tymczasem jako Matka Elżbieta wyznacza inny kierunek stosunku do ludzi niewidomych - podmiotowe podejście oparte na miłości bliźniego. „Podstawą życia w Laskach musi być miłość. [...] Miłość, która widzi istotną wartość człowieka, nie zważając na usterki lub drobne śmieszności. Miłość, która potrafi karcić, gdy tego zachodzi potrzeba, mając na względzie dobro osoby, którą się karci, i dobro jej otoczenia"6.

Urzeczywistniać się osobowo, spełniać w swoim człowieczeństwie znaczy „doprowadzać do właściwej pełni tę strukturę, która jest dla człowieka znamienna $[\ldots]$ z tej racji, że jest kimś, a nie czymś’" Fakt bycia osobą ludzką wskazuje na naturalną wielkość człowieka, na jego nadrzędną pozycję wobec przyrody i tego, z czym spotyka się w świecie. Uznawać zatem godność człowieka to tyle, co stawiać jego samego ponad wszystkim, co od niego pochodzi ${ }^{8}$. Stawiać go także ponad jego predyspozycjami, ponad jego kondycją zdrowotną, zdolnościami czy sprawnościami. „Wychowanie są to sposoby i procesy, które pozwalają wychowankowi odnaleźć się w swoim człowieczeństwie [...]"9. Takie podejście było bardzo bliskie Matce Czackiej, która pomagała swoim niewidomym podopiecznym uruchomić wszelkie możliwości, zdolności, nawet te ukryte, uśpione, zmarginalizowane. Jej mądrość wychowawcza ma swe źródło w rozpoznaniu istoty człowieczeństwa, niezbywalnej wartości każdej istoty ludzkiej. To z kolei pozwoliło jej zawsze patrzeć na drugiego jako istotę potencjalną, mającą swe możliwości i mogącą - mimo ograniczeń - realizować się w swoim człowieczeństwie.

4 Andrzej Szostek, Pogadanki z etyki (Lublin: Redakcja Wydawnictw KUL 1996), 22.

5 „Kalectwo Róży trzymano w tajemnicy. Gdy o nią pytano, padała odpowiedź, że ją głowa boli. [...] Gdyby nie służba, która rozniosła prawdziwe informacje, nikt nie poznałby prawdy. Ślepota była w domu uważana za coś poniżającego, za jakąś hańbę i do końca się z tym ukrywano" Anna Branicka, Wspomnienia o Matce Elżbiecie Czackiej (Laski: Archiwum Sióstr Franciszkanek Służebnic Krzyża 1936), 5.

6 Matka Elżbieta Czacka, Dyrektorium (Laski: Zgromadzenie Sióstr Franciszkanek Służebnic Krzyża 2008), 159. W swoich Notatkach Matka Elżbieta wskazuje konkretne gesty pełne miłości i serdeczności oraz wyraz twarzy, co potwierdza, że to właśnie miłość wyznaczała jej kierunek postępowania względem drugiego człowieka: „Do rzędu uczynków miłosiernych chciałabym zaliczyć dobroć i serdeczność, uprzejmość w zetknięciu się z ludźmi. Ile dobrego w ten sposób zrobić można! Już sam wyraz twarzy uprzejmy, pogodny i łagodny, ile spokoju wlewa do duszy bliźniego. Intonacja głosu serdeczna, łagodna, życzliwa, ile może dodać otuchy [...]”. Matka Elżbieta Czacka, Notatki (Laski: Zgromadzenie Sióstr Franciszkanek Służebnic Krzyża 2015), 56.

7 Karol Wojtyła, Osoba i czyn oraz inne studia antropologiczne (Lublin: Towarzystwo Naukowe KUL 1994), 196.

8 Tamże, 418.

9 Klaus Schaller, „Erziehung”, w: Wörterbuch der Pädagogik (Freiburg: 1977), t. 1, 248, za: Marian Nowak, „Osoba i wartość w pedagogice ogólnej”, w: Antropologiczna pedagogika ogólna, red. Marian Nowak, Piotr Magier, Iwona Szewczak (Lublin: GAUDIUM 2010), 52. 
„W wychowaniu bowiem chodzi właśnie o to, ażeby człowiek stawał się coraz bardziej człowiekiem"10, stawał się bogatszy jako osoba ludzka. Wychowanie zgodnie z określeniem wskazanym przez Jana Pawła II - jest to proces doskonalenia się człowieka, zmierzający do aktualizowania pełni jego człowieczeństwa poprzez odkrywanie prawdy o sobie i świecie ${ }^{11}$. Witold Starnawski powiada, że „Zrozumieć, kim jest człowiek, to przyjąć, że jest on kimś więcej, niż jest”12. $\mathrm{W}$ formule tej zawarta jest istota wychowania. Albowiem polega ono w swej najgłębszej naturze na docenieniu jednostki, która jest nieskończona, a tym samym na uznaniu formacji za proces nigdy niedokończony, za dzieło narażone na niepowodzenie, nieprzewidywalne, a jednocześnie konkretne i żywe ${ }^{13}$. „Wychowywać znaczy wobec tego pomagać komuś w odkryciu własnych «możliwości», pomagać w zrozumieniu, kim człowiek powinien «być», aby naprawdę odpowiedział na swe powołanie. Człowiek bowiem jest istotą obdarzoną ogromnym potencjałem i w tym tkwią możliwości jego wychowania"14.

Założycielka Towarzystwa Opieki nad Ociemniałymi miała świadomość rangi osoby ludzkiej - zdrowej czy kalekiej. Wiedziała, że w każdym są obecne różne możliwości i należy je niejako uruchomić, czasem odkryć. „Dla Róży Czackiej człowiek był najważniejszy, z pełnym zrozumieniem i ciepłem podchodziła do wszystkich"15. Wielokrotnie upominała swoich współpracowników, gdy ci traktowali osoby z dysfunkcją wzroku, jakby były ograniczone we wszelkich sferach. Przypominała o ich osobowej wartości, sferze uczuć i intelektu. Zwracała uwagę, że są pełnowartościowymi osobami. „Zdarza się, że widzący w zupełnym niezrozumieniu niewidomego mówią o nim przy nim tak, jakby on nie tylko nie widział, ale i nie słyszał, a co ważniejsze, nie rozumiał tego, co się o nim mówi”"16. Często podkreślała, że: „Człowiek pozbawiony jednego zmysłu, a nawet jak uczy nas przykład głucho-ciemnych, dwóch zmysłów, nie jest skazany na bytowanie roślinne, ale może w sobie zrealizować pełnię najwyższego życia ludzkiego - życie duchowe"17. Człowiek jest osobą. Jej transcendencja w czynie przejawia się najpełniej, gdy poprzez swoje działania afirmuje drugiego człowieka, traktuje go zawsze jako cel swoich działań. Każdy z nas - zdrowy i chory - potrzebuje sza-

10 Jan Paweł II, „W imię przyszłości kultury” (Przemówienie do przedstawicieli UNESCO, Paryż 2 VI 1980), L'Osservatore Romano 6 (1980): 4.

11 Tamże, 4-6.

12 Witold Starnawski, „Wychowanie do prawdy - powinnością szkoły”, Ethos 75 (2006): 80.

13 Furio Pesci, „Filozoficzna perspektywa wychowania”, tłum. Patrycja Mikulska, Ethos 75 (2006): 37.

14 Stanisław Chrobak, Podstawy pedagogiki nadziei (Warszawa: Uniwersytet Kardynała Stefana Wyszyńskiego 2009), 400.

15 Michał Żółtowski, Blask prawdziwego światła. Matka Elżbieta Róża Czacka i jej dzieło (Lublin: P.H.U. Impuls Ryszard Dziewa 2005), 71.

16 Matka Elżbieta Czacka, O niewidomych (Warszawa: Wydawnictwo Uniwersytetu Kardynała Stefana Wyszyńskiego 2008), 157-158.

17 Tamże, 159. 
cunku i miłości, by nie pozostać osobą wyłącznie na płaszczyźnie ontycznej, ale stać się nią faktycznie - urzeczywistniając swoje człowieczeństwo.

\section{Podstawowe błędy w wychowaniu osób niewidomych}

W procesie wychowania osób $\mathrm{z}$ dysfunkcją wzroku nierzadko popełniane są różne błędy, zarówno w środowisku rodzinnym, jak i ze strony wychowawców w placówce. Na takie mankamenty wskazywała Matka Czacka, która sama jako osoba niewidoma doskonale znała sytuację ludzi pozbawionych zmysłu wzroku. Z autopsji wiedziała, co jest niezbędne dla ich prawidłowego rozwoju oraz co może zaszkodzić, okaleczyć ich człowieczeństwo.

Ze wspomnień najbliższych jej osób wynika, że kiedy Róża Czacka straciła wzrok i mieszkała w swoim domu rodzinnym, była bardzo samodzielna w swym kalectwie, a przy tym dokładna, czysta i staranna: „Dbała o to, aby swój pokój w porządku utrzymywać [...] sama się ubrała, uczesała, a ubrana zawsze była starannie i uczesana" ${ }^{\prime 1}$. Sama podróżowała, nie stroniła od codziennych prac, wykonywała różne kobiece zajęcia: „Była doskonale zrehabilitowaną niewidomą, podróżującą bez przewodniczki, tylko ze swą nieodłączną laseczką. Całe dnie spędzała, wykonując jakąś ręczną robótkę"19.

Niewłaściwy stosunek do osób z dysfunkcją wzroku, izolowanie, powoduje, że ich niepełnosprawność staje się jeszcze bardziej tragiczna. Ograniczenia obejmujące ciało rozciągają się bowiem wówczas na inne sfery: czują się oni bezużyteczni, wykluczeni z wszelkich form współżycia, niekochani, jednym słowem wyrzuceni poza margines życia społecznego ${ }^{20}$. Tworzenie dystansu, izolowanie czy wręcz wykluczanie osób niewidomych jest też często efektem braku umiejętności reagowania na ten rodzaj niepełnosprawności. Inicjatorka Dzieła Lasek w wielu swoich pismach podkreśla, że osoby niewidome są zwyczajnymi ludźmi, „[...] nie należy traktować niewidomych jako jakiejś odrębnej kasty ludzi, odmiennego od innych gatunku, lecz jako ludzi zwykłych, którym brak wzroku"21.

Błędne wychowanie niewidomych, które krytykowała Matka Czacka, polegało również na wyręczaniu osób z dysfunkcją wzroku. Twierdziła, że „Wiele osób myśli, że dobra opieka nad niewidomymi polega na tym, by im we wszystkim

18 Branicka, Wspomnienia, 9.

19 Helena Czartoryska, Relacja ustna, za: Żółtowski, Blask, 70.

20 Livio Maritano, „Uprzywilejowana pozycja «ostatnich»”, tłum. Karol Klauza, Ethos 6/7 (1989): 66.

${ }^{21}$ Rut Wosiek, „Podstawy ideowe Dzieła Lasek”, w: Chrześcijanie, red. Bohdan Bejze (Warszawa: Akademia Teologii Katolickiej 1976), t. 2, 239. W książce O niewidomych Matka Elżbieta Czacka w odniesieniu do niewidomego zaznacza, że „Rani go [...] współczujące zainteresowanie widzącego, gdy niesie on zbyteczną usługę. Wtedy poczucie niższości może przerodzić się w kompleks głęboki, wypaczający u podstaw charakter niewidomego". Czacka, O niewidomych, 184. 
pomagać, a nawet usługiwać, by uchylać od nich wszelki wysiłek, odsuwać wszelkie przeszkody"22. Gdy tymczasem jest to niewłaściwy kierunek, który przyczynia się z jednej strony do braku samodzielności niewidomych, z drugiej zaś do lenistwa, powstawania postaw roszczeniowych i egoistycznych. Ważne jest, by już w środowisku rodzinnym nie przejawiać zbyt daleko posuniętej opieki, ponieważ „jest to atmosfera najgorsza dla dziecka niewidomego, gdyż zamiast pobudzać, podcina w nim wszelką aktywność [...] do jednego kalectwa dodaje drugie gorsze - niedołęstwo" ${ }^{23}$. Istotne jest, by wychowawca sprawujący opiekę nad niewidomym w placówce posiadał wiedzę dotyczącą przygotowania go do samodzielnego życia i nie powielał błędów rodzicielskich ograniczających samodzielność podopiecznych. Powinien mieć świadomość, w czym pomagać, w jakim stopniu i w jaki sposób, by nadmierną opieką nie doprowadzić do sytuacji, wskutek której wychowanek z dysfunkcją wzroku „zostanie na całe życie niedołężnym gapą"24.

Założycielka Zgromadzenia Franciszkanek Służebnic Krzyża w procesie wychowywania niewidomych przestrzegała przed tzw. kolaboracją niewidomego $\mathrm{z}$ widzącym. Chodziło tutaj o jedynie częściowe dopuszczanie osoby z dysfunkcją wzroku do wykonywania określonej czynności. Matka Elżbieta podkreślała ważność samodzielności w dążeniu do celu. Wychowawca powinien czuwać, nie zaś wyręczać. Mądre pokierowanie rozwojem osoby niewidomej daje szansę na prawdziwe usamodzielnienie człowieka pozbawionego zdolności widzenia.

Inicjatorka Triuno, udzielając wskazówek wychowawczych osobom zajmującym się niewidomymi, dawała cenne rady dotyczące utartych przez lata schematów, a wszystkie jej działania zmierzały do wychowania człowieka zaradnego życiowo. Zamiast zatrzymywać się nad swoją trudną sytuacją, niewątpliwie ciężkim kalectwem, mobilizowała osoby niewidome, żeby usprawniać to, co w nich niesprawne. Dlatego błędne w jej oczach było takie wychowanie osób z dysfunkcją wzroku, które zmierzało do izolacji ociemniałych dzieci na skutek różnych zachowań czy gestów. Podkreślała np., że „Nigdy dzieciom nie powinno się pozwalać, aby wyciągały ręce przed siebie, gdy chodzą lub biegają. Powinny w ruchach swoich jak najmniej różnić się od dzieci widzących"25.

Umiejętność dostrzegania człowieka $\mathrm{w}$ osobie doświadczonej niepełnosprawnością wzrokową, zwyczajnego i wartościowego, pozwoliła Matce Czackiej właściwie służyć niewidomym. Służba ta sprowadzała się do traktowania niepełnosprawności jako trudnego wprawdzie doświadczenia, jednak nie

22 Tamże, 35-36.

23 Tamże, 170.

24 Tamże, 86: „[...] nie nauczy się nigdy samodzielnie chodzić, jeśli się go będzie zawsze za rękę prowadziło. Trzeba zostawić, by niewidomy uczył się sam, a wychowawca musi tylko czuwać nad takim niewidomym, który się tego uczy. [...] Gdy się ociemniałego prowadzi za rękę, nie zwraca on uwagi na to np., gdzie jest wystający kamień, gdzie się z bruku schodzi na miękką drogę itd.”.

25 Tamże, 53. 
ograniczającego człowieka do przyjmowania biernej postawy i życia całkowicie zależnego od innych.

\section{Wychowanie dziecka z dysfunkcją wzroku}

Celem wychowania w rozumieniu Matki Elżbiety Róży Czackiej jest troska o integralny „rozwój w wymiarze duchowym, intelektualnym, psychicznym, zdrowotnym, społeczno-moralnym i estetycznym ${ }^{26}$. Integralne rozumienie procesu wychowania akcentuje, by uwzględniać $\mathrm{w}$ wychowaniu wszystkie podstawowe sfery człowieczeństwa, a zatem sferę cielesną, intelektualną, emocjonalną, moralną, duchową, religijną, społeczną, a także sferę wartości i wolności. W sposób szczególny „poszukiwanie integralnego i realistycznego ujęcia «wychowania» domaga się [...] uwzględnienia w nim wymiaru duchowego i religijnego"27.

Życie duchowe stanowiło fundament całego życia Założycielki Zgromadzenia Franciszkanek Służebnic Krzyża. Jako osoba głęboko religijna, która w Bogu odnalazła sens swojego kalectwa, w świetle wiary uczyła swoich podopiecznych akceptować niepełnosprawność fizyczną. Miała świadomość, że „tylko głębokie życie wiary i mądre wychowanie $\mathrm{w}$ jej duchu może uchronić niewidomego od zgorzknienia, nieufności, podejrzliwości, fałszywej pokory [...] Jednak przykład niewidomych o harmonijnej i zrównoważonej sferze uczuciowej, o uczuciach wyjątkowo czystych i delikatnych świadczy, że tak częste [...] przewrażliwienia niewidomych są skutkiem nie ich kalectwa, ale warunków życia i nieodpowiedniego wychowania"28.

Niezwykła mądrość wychowawcza Matki Czackiej widoczna jest w całej postawie Założycielki Triuno wobec osób niewidomych. Dążyła ona do doprowadzenia osób z dysfunkcją wzroku do samodzielnej, możliwie niezależnej od innych egzystencji. Już od najwcześniejszych lat życia niewidomego należy „tak urządzić warunki życia, by w domu, przy ubieraniu, w zwykłych zajęciach i w pracy zawodowej nie potrzebował pomocy widzących. W tym zakresie należy rozwijać w nim inicjatywę, zmysł organizacji, samodzielność, poczucie samowystarczalności [...]"29. Podopieczni przebywający w Laskach stopniowo przygotowywani są do przyszłego, samodzielnego życia. Wykonują różne prace domowe i gospodarcze: przygotowują różne potrawy, są wdrażani do utrzymania

26 Barbara Landowska, „Aktualność koncepcji wychowawczej Matki Elżbiety Róży Czackiej w realizacji Programu Dydaktyczno-Wychowawczego w Internacie Dziewcząt w Ośrodku Szkolno-Wychowawczym dla Dzieci Niewidomych w Laskach”, w: Wspótczesna recepcja myśli Matki Elżbiety Róży Czackiej. Wychowanie, red. Jadwiga Kuczyńska-Kwapisz (Warszawa: Wydawnictwo Uniwersytetu Kardynała Stefana Wyszyńskiego 2012), 8.

27 Chrobak, Podstawy pedagogiki, 349.

28 Czacka, O niewidomych, 165.

29 Tamże, 36. 
porządku w miejscu nauki i odpoczynku. Matka Elżbieta wskazywała, że „każdy bez wyjątku niewidomy pomocy widzących w pewnej mierze potrzebuje i zawsze potrzebować będzie. Cała mądrość wychowania niewidomych [...] polega na tym, by niewidomy mógł z siebie dać maksimum inicjatywy, wysiłku, zaradności i pracy"30.

Mądra postawa Inicjatorki Dzieła Lasek wobec osób z dysfunkcją wzroku, a później również takie podejście ze strony członków Towarzystwa Opieki nad Ociemniałymi uświadamiały ważną prawdę, że „pozbawiony wzroku człowiek może być czynny, użyteczny i wartościowy" ${ }^{31}$.

Wychowanie osób niewidomych powinno polegać na zapewnieniu tych wszystkich czynników, które dziecko widzące naturalnie poznaje na drodze obserwacji. W przypadku wychowanków pozbawionych doświadczeń wzrokowych oraz wzrokowego poznania otaczających go rzeczy należy obudzić w nim zainteresowanie światem zewnętrznym. A zatem „odmienność dróg w wychowaniu dziecka ociemniałego polega przede wszystkim na tym, że trzeba mu dostarczyć tych wszystkich czynników, które u widzącego są już dane w jego doświadczeniu”32. Mądrość wychowawcza Matki Elżbiety zawsze w centrum stawiała wartość prawdy. Założycielka Triuno przestrzegała rodziców przed uporczywym posyłaniem dzieci do szkół dla dzieci widzących. Wiedziała, że owocne wychowanie niewidomego musi mieć odpowiednio przygotowany personel, a przede wszystkim dobrane metody i pomoce, które zapewnią optymalny rozwój wychowanka. Podkreślała, że

[...] dziecko, którego wzrok jest zagrożony lub za słaby, aby pozwalał na normalną naukę, należy uzbroić w metody i pomoce, które dziecku niewidomemu zapewniają możność normalnego rozwoju umysłowego i użytecznej pracy w przyszłości. Niestety, najczęściej się zdarza, że otoczenie [...] nie chce odważnie spojrzeć prawdzie w oczy i nie może się zdecydować na kształcenie dziecka odpowiednio do jego możliwości. [...] Ci, którzy mają tego rodzaju stosunek do ślepoty, nie zdają sobie nieraz sprawy, że mimo woli narażają swoje dziecko na większe stokroć kalectwo niedołęstwa $[\ldots]^{33}$.

Matka Elżbieta Róża Czacka duży nacisk kładła na dbałość o odpowiednią atmosferę $\mathrm{w}$ procesie wychowania niewidomych. Zabiegała, aby wychowanie w Laskach było zbliżone do rodzinnego, oparte na miłości do dziecka, atmosferze pełnej życzliwości, wsparcia, pełnej akceptacji, a jednocześnie nie wolne od stawiania wymagań ${ }^{34}$. Atmosfera ta przeniknięta była szacunkiem wobec drugiego

30 Tamże, 47.

31 Żółtowski, Blask, 67.

32 Czacka, O niewidomych, 78.

3 Tamże, 40-41.

34 Jadwiga Kuczyńska-Kwapisz, „Aktualność myśli tyflologicznej Matki Elżbiety Róży Czackiej”, w: Środowisko Lasek a perspektywa historii i chrześcijańskiej myśli pedagogicznej, red. Józef Placha (Warszawa: Wydawnictwo Uniwersytetu Kardynała Stefana Wyszyńskiego 2011), 264. 
człowieka, miłością, oparta na głębokim życiu wewnętrznym. Matka Czacka nie traktowała niewidomego dziecka jak „nieszczęśliwego kaleki”, któremu należy wynagrodzić cierpienie - pozwalając na wszystko, jak ma to miejsce w wielu domach. Jej chodziło o prawdziwe dobro wychowanka. Założycielka Towarzystwa Opieki nad Ociemniałymi wiedziała bowiem, że tylko „odpowiednio gruntowne wychowanie otrzymane $\mathrm{w}$ dzieciństwie da niewidomemu siły do zwycięskiego przejścia przez ten trudny okres i do stania się pełnowartościowym indywidualnie i społecznie człowiekiem"35.

Troska Założycielki Dzieła Lasek o integralny rozwój człowieka pozbawionego zdolności widzenia, a w niej akcentowanie wymiaru duchowego i religijnego miała swoje mocne uzasadnienie. Spoglądając na swoje życie doświadczone cierpieniem, wiedziała, że „żaden system pedagogiczny i żaden oparty na nim humanitarny system pedagogiczny, nie daje takiego rozwiązania tego problemu, na którym mogłoby się oprzeć w pełni życie człowieka cierpiącego. Jedynie religia Krzyża i Zmartwychwstania daje wytłumaczenie sensu cierpienia [...]"36. Człowiek, który odkryje sens cierpienia, przyjmie swoje kalectwo jako środek prowadzący do uświęcenia, nie będzie czuł pustki i ciężaru ograniczeń w swojej egzystencji. Odkryje natomiast ważną prawdę - o wartości swojego człowieczeństwa.

\section{Rola wychowawcy w pracy z niewidomymi}

Sięgając do pism Elżbiety Róży Czackiej, w których jest mowa o pracy wychowawcy z niewidomymi i słabowidzącymi, można dostrzec, że kluczową sprawą, podkreślaną $\mathrm{w}$ wielu miejscach, jest posiadanie przez pedagoga odpowiednich kwalifikacji i kompetencji zawodowych. „Osoby, które chcą zajmować się niewidomymi, powinny przede wszystkim zaznajomić się z całą teoretyczną stroną sprawy i poznać w ten sposób rezultaty, do jakich można dojść w wychowaniu lub reedukacji niewidomych" ${ }^{37}$.

Wychowanie w każdym wypadku powinno stanowić pomoc w „scalaniu się” człowieka, w jego dojrzewaniu i pokonywaniu ludzkiej niedoskonałości ${ }^{38}$. W wychowawczej pracy wychowawcy nad wychowankiem ujawnia się zatem metafizyka pomocy. Wspomniana relacja to rodzaj służby. Wychowawca zostaje obdarzony powołaniem służenia pomocą uczniowi.

W wyjątkowy sposób brzmi słowo „służba”, gdy dotyczy wychowanka z dysfunkcją wzroku. Wychowawca osoby niewidomej ma za zadanie zapoznawać ją

35 Czacka, O niewidomych, 184.

36 Matka Elżbieta Czacka, Ideowe Założenia Dzieła, Towarzystwo Opieki nad Ociemniałymi (Laski: Archiwum Sióstr Franciszkanek Służebnic Krzyża 1945), mps.

37 Taż, O niewidomych, 34 .

38 Giacomo Cives, La mediazione pedagogica (Firenze: La Nuova Italia 1973), IX, za: Pesci, Filozoficzna perspektywa wychowania, 41. 
$\mathrm{z}$ otoczeniem, rozwijać jej zainteresowanie światem, zachęcać do różnych form aktywności, ukazywać sens pracy nad sobą. Wychowawca ten winien być cierpliwym, wytrwałym i pracowitym poszukiwaczem pełni i harmonii wychowanka. Do spotkania $\mathrm{z}$ takim nauczycielem dochodzi wyłącznie na gruncie miłości. Tylko wówczas ma on moc odmiany życia wychowanka.

Cierpliwość znamionująca wychowawcę osób z dysfunkcją wzroku powinna być trojaka: „Znosząca bez zniecierpliwienia nieudolność dzieci. Nie spiesząca się, by dana robota była wykonana za wszelką cenę, choćby rękoma osoby pokazującej. Umiejąca bez końca wracać do nauczania wciąż tych samych rzeczy"39. Jednym słowem - „wychowawca musi mu zastąpić oczy” ${ }^{40}$.

Wychowawca niewidomych powinien być daleki od nadmiernego rozczulania się nad ograniczeniami fizycznymi swoich podopiecznych. Matka Czacka mawiała, że „pozornie jest on twardy" ${ }^{2}$. Nie ma bowiem wychowania bez wymagań; tych wymagań, które otwierają nowe perspektywy, uczą, jak sprostać wyzwaniom, jak nie ulegać trudnościom, jak urzeczywistniać ważne cele. W stawianiu wymagań ważne jest, „by wychowawca zdawał sobie sprawę z możliwości ociemniałego i tego, czego od niego może wymagać, bo każdy niewidomy ma swój własny zakres możliwości zależny od tego, jaki jest stopień jego ociemniałości i jak umie wykorzystywać ten skrawek pola widzenia, jaki często ma jeszcze zdrowy"42. Rola wychowawcy w rozumieniu Założycielki Triuno sprowadzała się nie do tkliwej opieki i prowadzenia niewidomego za rękę, ale do udzielenia mu faktycznej pomocy poprzez wprowadzenie go w dojrzałe i samodzielne życie.

Koncepcję wychowania Elżbiety Róży Czackiej znamionuje wartość prawdy. Matka Czacka, stawiając wymagania swoim podopiecznym, jednocześnie uświadamiała im ograniczenia wynikające z kalectwa. Przestrzegała wychowawców przed rozwijaniem $\mathrm{w}$ niewidomych dzieciach i młodzieży nierealnych planów dotyczących ich przyszłości ${ }^{43}$.

Jeszcze dzieci w wieku szkolnym, choć rozumieją, że są pozbawione jakiejś cennej władzy, którą posiadają inni, nie odczuwają jednak boleśnie swojej ślepoty [...]. Mądry wychowawca powinien korzystać z tego okresu dla dobra postawienia w prawdzie niewidomego wobec jego kalectwa. Oto czas, kiedy należy w nim wychować

39 Regulamin Wychowawczy Domu Św. Antoniego (Laski: Towarzystwo Opieki nad Ociemniałymi 1948-1949), mps.

40 Czacka, O niewidomych, 79.

41 Matka Elżbieta Czacka, „Triuno”, w: Chrześcijanie, red. Bohdan Bejze (Warszawa: Akademia Teologii Katolickiej 1976), t. 2, 256.

${ }_{42}$ Czacka, $O$ niewidomych, 91.

43 „Nie dla niewidomego chłopca marzenia o bohaterstwie na polu walki [...] o wielkich wyczynach lotniczych czy żeglarskich [...]. Nie dla dziewczyny niewidomej te zawody [...] nie będzie ona opiekunką maleństw ani pielęgniarką, ani lekarzem [...]”. Tamże, 184. 
prawość i prostotę, nauczyć go, aby nie udawał tych możliwości, których w nim nie ma, i nie wstydził się tych ograniczeń, które ślepota mu narzuca ${ }^{44}$.

Matka Elżbieta Czacka podkreślała rolę doświadczenia w procesie wychowania. Wychowawca powinien wykorzystywać wszystkie sytuacje w celu wypracowania u swoich podopiecznych różnych umiejętności, zwłaszcza orientacji słuchowej $^{45}$. O wiele ważniejsze jest bowiem to, co dziecko ociemniałe pozna w realnych, bezpośrednich sytuacjach, niż podczas - nawet najbardziej twórczo przeprowadzonych lekcji.

Najbardziej owocną metodą wychowania, na którą wskazywała Inicjatorka Triuno, jest dawanie dobrego przykładu. Mówiła, że: „Wychowawca powinien wychowywać przede wszystkim przykładem"46. Wówczas wartości przeżywane przez wzór osobowy mogący być dla młodego człowieka bohaterem, przenikając jego egzystencję i kształtując osobowość, mogą w końcu być przekazywane innym, wpływać na ich postawy, słowa i postępowanie ${ }^{47}$.

\section{Konkluzja}

Każdy człowiek jest istotą słabą. Kruchość istnienia dotyka każdego z nas w wielu sferach. Człowiek niewidomy, na skutek licznych barier i ograniczeń wpisanych w jego niepełnosprawność, w pewien sposób zostaje odizolowany od różnych dóbr. Wielkość każdego człowieka tkwi w samoświadomości jego nędzy, niedoskonałości, kruchości. Mądrość wychowawcza Matki Czackiej sprowadzała się przede wszystkim do szacunku wobec istoty ludzkiej. Jej roztropność stawiała w centrum wartość prawdy - nie rozwijała $\mathrm{w}$ wychowankach nierealnych pragnień. Wiedziała, że niepełnosprawność wzrokowa jest ciężkim ograniczeniem, ale potrafiła przyjąć ją jako dar i tego samego uczyła swoich podopiecznych. Wiara w Boga stanowiła fundament jej całego życia. Tą drogą prowadziła swoich podopiecznych do możliwie pełnego ich usamodzielnienia i życia na miarę człowieka obdarzonego godnością.

Streszczenie: Specyficznym rodzajem interakcji międzyludzkiej jest stosunek wychowawcawychowanek. Na tej płaszczyźnie ujawnia się metafizyka pomocy - wychowawca zobowiązany

44 Tamże, 181.

45 „Na przykład odbywa się lekcja i nauczyciel słyszy za oknem odgłos jakiejś pracy: powinien natychmiast przerwać lekcję i zainteresować dzieci tymi odgłosami, a nawet nie wahać się zaprowadzić je tam, gdzie ta praca się odbywa. [...]”. Albo inna sytuacja: „upadło coś metalowego czy szklanego, czy drewnianego - niewidomy musi to słuchem odróżnić, jaki przedmiot upadł, i od razu umiejscowić ten dźwięk". Tamże, 80.

46 Tamże, 39.

47 Henryk Noga, „Wzór osobowy jako nośnik wartości”. Wychowawca 6 (2004): 11-13. 
jest wspierać wychowanka w dochodzeniu do pełni człowieczeństwa. Taka postawa znamionuje Założycielkę Towarzystwa Opieki nad Ociemniałymi - Matkę Elżbietę Różę Czacką, która pomagała swoim niewidomym podopiecznym uruchomić wszelkie możliwości i zdolności, zwłaszcza te ukryte i zmarginalizowane, by w konsekwencji doprowadzić ich do możliwie samodzielnego i niezależnego od innych życia. Fenomen koncepcji wychowawczej Róży Czackiej - oprócz afirmacji godności osobowej swoich podopiecznych - polega na respektowaniu wartości prawdy, konsekwencji i stawianiu realnych wymagań wobec osób z dysfunkcją wzroku. Sama będąc osobą pozbawioną zdolności widzenia, wiedziała, że ten rodzaj niepełnosprawności jest ciężkim ograniczeniem, ale potrafiła z perspektywy wiary w Boga odnaleźć sens swojego życia, jakim stała się służba niewidomym, zwłaszcza dzieciom.

Słowa kluczowe: wychowanek, wychowawca, niepełnosprawność wzrokowa, godność osobowa, cierpienie

\section{Bibliografia}

Branicka, Anna. Wspomnienia o Matce Elżbiecie Czackiej. Laski: Archiwum Sióstr Franciszkanek Krzyża, 1936.

Chrobak, Stanisław. Podstawy pedagogiki nadziei. Warszawa: Wydawnictwo Uniwersytetu Kardynała Stefana Wyszyńskiego, 2009.

Chudy, Wojciech. Pedagogia godności. Elementy etyki pedagogicznej, red. Anna Szudra. Lublin: Towarzystwo Naukowe KUL, 2009.

Cives, Giacomo. La mediazione pedagogica. Firenze: La Nuova Italia, 1973.

Czacka, Matka Elżbieta. Notatki. Laski: Zgromadzenie Sióstr Franciszkanek Służebnic Krzyża, 2015.

Czacka, Matka Elżbieta. Dyrektorium. Laski: Zgromadzenie Sióstr Franciszkanek Służebnic Krzyża, 2008.

Czacka, Matka Elżbieta. O niewidomych. Warszawa: Wydawnictwo Uniwersytetu Kardynała Stefana Wyszyńskiego, 2008.

Czacka, Matka Elżbieta. „Triuno”. W: Chrześcijanie, red. Bohdan Bejze, t. 2, 253-261. Warszawa: Akademia Teologii Katolickiej, 1976.

Czacka, Matka Elżbieta. Ideowe Założenia Dzieła, Towarzystwo Opieki nad Ociemniałymi. Laski: Archiwum Sióstr Franciszkanek Służebnic Krzyża, 1945.

Czartoryska, Helena. Relacja ustna, za: Michał Żółtowski. Blask prawdziwego światła. Matka Elżbieta Róża Czacka i jej dzieło. Lublin: P.H.U. Impuls Ryszard Dziewa, 2005.

Jan Paweł II. „W imię przyszłości kultury”. (Przemówienie do przedstawicieli UNESCO, Paryż 2. VI 1980). L'Osservatore Romano 6 (1980): 4-6.

Kuczyńska-Kwapisz, Jadwiga. „Aktualność myśli tyflologicznej Matki Elżbiety Róży Czackiej”. W: Srodowisko Lasek a perspektywa historii i chrześcijańskiej myśli pedagogicznej, red. Józef Placha, 252-270. Warszawa: Wydawnictwo Uniwersytetu Kardynała Stefana Wyszyńskiego, 2011.

Landowska, Barbara. „Aktualność koncepcji wychowawczej Matki Elżbiety Róży Czackiej w realizacji Programu Dydaktyczno-Wychowawczego w Internacie Dziewcząt w Ośrodku Szkolno-Wychowawczym dla Dzieci Niewidomych w Laskach". W: Współczesna recepcja myśli Matki Elżbiety Róży Czackiej. Wychowanie, red. Jadwiga Kuczyńska-Kwapisz, 7-37. Warszawa: Wydawnictwo Uniwersytetu Kardynała Stefana Wyszyńskiego, 2012.

Maritano, Livio. „Uprzywilejowana pozycja «ostatnich»”, tłum. Karol Klauza. Ethos 6/7 (1989): 65-76. 
Noga, Henryk. „Wzór osobowy jako nośnik wartości”. Wychowawca 6 (2004): 11-13.

Nowak, Marian. „Osoba i wartość w pedagogice ogólnej”. W: Antropologiczna pedagogika ogólna, red. Marian Nowak, Piotr Magier, Iwona Szewczak 41-56. Lublin: GAUDIUM, 2010.

Pesci, Furio. „Filozoficzna perspektywa wychowania”, tłum. Patrycja Mikulska. Ethos 75 (2006): 37-51.

Regulamin Wychowawczy Domu Św. Antoniego. Laski: Towarzystwo Opieki nad Ociemniałymi, 1948-1949.

Starnawski, Witold. „Wychowanie do prawdy - powinnością szkoły”. Ethos 75 (2006): 75-87.

Szostek, Andrzej. Pogadanki z etyki. Lublin: Redakcja Wydawnictw KUL, 1996.

Wojtyła, Karol. Osoba i czyn oraz inne studia antropologiczne. Lublin: Towarzystwo Naukowe KUL, 1994.

Wosiek, Rut. „Czacka Róża”. W: Encyklopedia katolicka, red. Romuald Łukaszyk, Ludomir Bieńkowski, Feliks Gryglewicz, t. 3, 745-746. Lublin: Towarzystwo Naukowe KUL, 1979.

Wosiek, Rut. „Podstawy ideowe Dzieła Lasek”. W: Chrześcijanie, red. Bohdan Bejze, t. 2, $227-$ 240. Warszawa: Akademia Teologii Katolickiej, 1976.

Żółtowski, Michał. Blask prawdziwego światła. Matka Elżbieta Róża Czacka i jej dzieło. Lublin: P.H.U. Impuls Ryszard Dziewa, 2005. 